\title{
A dohányzás és az alkoholfogyasztás együittes előfordulásának összefüggései a figyelemhiányos hiperaktivitás-zavar tüneteivel kilencedik osztályos tanulók körében
}

\author{
Matuszka Balázs ${ }^{1,2}$. Bácskai Erika dr. ${ }^{3}$ - Czobor Pál dr. ${ }^{4,5}$ \\ Egri Tímea ${ }^{6}$ - Gerevich József dr. ${ }^{3,6}$ \\ ${ }^{1}$ Pázmány Péter Katolikus Egyetem, Bölcsészet- és Társadalomtudományi Kar, Pszichológia Intézet, Budapest \\ ${ }^{2}$ Semmelweis Egyetem, Mentális Egészségtudományok Doktori Iskola, Budapest \\ ${ }^{3}$ Addiktológiai Kutató Intézet, Budapest \\ ${ }^{4}$ Semmelweis Egyetem, Általános Orvostudományi Kar, Pszichiátriai és Pszichoterápiás Klinika, Budapest \\ ${ }^{5}$ Nathan Kline Institute for Psychiatric Research, Orangeburg, NY, Amerikai Egyesült Államok \\ ${ }^{6}$ Eötvös Loránd Tudományegyetem, Bárczi Gusztáv Gyógypedagógiai Kar, Budapest
}

\begin{abstract}
Bevezetés: A figyelemhiányos hiperaktivitás-betegség korábbi vizsgálatok eredményei alapján összefüggésben áll a serdülőkori dohányzással és alkoholfogyasztással, azok kockázati tényezőjének tekinthető. Mivel a felnőttkorban kialakuló szenvedélybetegségek erős prediktora a figyelemhiányos hiperaktivitás-betegség, valamint a serdülőkori dohányzás és alkoholfogyasztás is, a később kialakuló addiktív problémák megelőzése szempontjából fontos a serdülökori összefüggések vizsgálata. Célkitüzés: A figyelemhiányos hiperaktivitás-betegség tüneteinek és az együttesen előforduló dohányzás és alkoholhasználat összefüggéseinek feltárása 9. osztályos serdülők körében. Módszer: A budapesti állami fenntartású középiskolák 9. osztályába járó fiatalok körében 944 elemú reprezentatív mintán általánosított lineáris kevert modellelemzéseket és logisztikusregresszió-elemzéseket végeztek. Eredmények: A jelenlegi dohányzás prevalenciája 29,6\%, a jelenlegi alkoholfogyasztásé 41,4\%, míg a két szer együttes használatáé 21,7\% volt. Az alkoholfogyasztás és a dohányzás szignifikáns pozitív összefüggést mutatott a Figyelemhiányos-Hiperaktivitás Zavar Skála pontszámaival, valamint a Figyelemzavar és a Hiperaktivitás/Impulzivitás Alskála pontszámaival. Következtetések: Az eredmények felhívják a figyelmet a figyelemhiányos hiperaktivitás-betegség tüneteinek szerepére az alkoholfogyasztás és dohányzás kialakulása szempontjából veszélyeztetett serdülők körében. Orv. Hetil., 2015, 156(43), 1750-1757.
\end{abstract}

Kulcsszavak: figyelemhiányos-hiperaktivitás zavar, alkohol, dohányzás, együttes használat, serdülők

\section{Associations between concurrent use of tobacco and alcohol and symptoms of attention-deficit hyperactivity disorder among ninth grader students}

\begin{abstract}
Introduction: Attention-deficit hyperactivity disorder is a risk factor of smoking and alcohol drinking in adolescence. Since attention-deficit hyperactivity disorder and smoking and alcohol drinking in adolescence are predictors for the development of substance use disorders in adulthood, it is important to understand the nature of these associations. Aim: The aim of the authors was to investigate associations between attention-deficit hyperactivity disorder symptoms and the joint use of alcohol and nicotine among 9th graders. Method: A representative sample of 944 pupils attending state-run secondary schools in Budapest were recruited. Generalized Linear Mixed Model and logistic regression analyses have been conducted. Results: The prevalence was $29.6 \%$ and $41.4 \%$ for current smoking and current alcohol drinking, respectively. The prevalence of their concurrent-use was $21.7 \%$. Alcohol drinking and smoking showed a significant positive association with the total scores of Attention-Deficit Hyperactivity Disorder Scale and with the Attention Deficit and Hyperactivity/Impulsivity subscales. Conclusions: The findings highlight the potential importance of attention-deficit hyperactivity disorder in the development of the joint use of these substances.
\end{abstract}


Keywords: attention-deficit hyperactivity disorder, alcohol, tobacco, concurrent use, adolescents

Matuszka, B., Bácskai, E., Czobor, P., Egri, T., Gerevich, J. [Associations between concurrent use of tobacco and alcohol and symptoms of attention-deficit hyperactivity disorder among ninth grader students]. Orv. Hetil., 2015, $156(43), 1750-1757$.

(Beérkezett: 2015. július 29.; elfogadva: 2015. augusztus 27.)

\begin{abstract}
Rövidítések
$\mathrm{ADHD}=$ attention-deficit hiperactivity disorder; EuroADAD $=($ European Version of the Adolescent Assessment Dialogue $)$ Serdülőkori Problémák Európai Értékelő Interjúja
\end{abstract}

A figyelemhiányos hiperaktivitás-betegség (attention-deficit hiperactivity disorder - ADHD) gyermekkorban kezdődő neuropszichiátriai tünetegyüttes. A szindróma vezető tünetei a figyelemzavar és a hiperaktivitás-impulzivitás, amelyek az iskolai, az otthoni és a társas feladatokban és kapcsolatokban is problémákat okoznak [1, 2]. A betegség prevalenciája az epidemiológiai vizsgálatok eredményei szerint 2 és 12\% közé tehető [2, 3], míg a szubklinikus súlyosságot elérő esetek becsült prevalenciája 0,8 és $23 \%$ közötti [2].

A gyermekkorban diagnosztizált betegek 70\%-a serdülőkorában is szenved a zavar tüneteitől, és az esetek 30-60\%-ában a tünetek a fiatal felnőttkorban is fennállnak [4]. A zavar felnőttkorban mért prevalenciája 4\% körüli $[1,5,6]$. Az ADHD szubklinikus és klinikai súlyosságot elérő formái egyaránt kapcsolatban állnak bizonyos internalizációs és externalizációs tünetekkel jellemezhető pszichiátriai zavarokkal $[2,7]$. Az ADHD-ban szenvedők között gyakori a dohányzás, az alkoholfogyasztás és a droghasználat megjelenése serdülő- és fiatal felnőtt korban [1, 8, 9]. Jól dokumentált jelenség, hogy az ADHD-ban szenvedő dohányosok fiatalabb korukban kezdenek el dohányozni, mint nem ADHD-s társaik, gyorsabban szoknak rá a napi szintü dohányzásra és nehezebben szoknak le róla [9]. Ez különösen igaz a kezeletlen ADHD-s betegekre [9]. Ez a hatás a komorbid viselkedészavar nélküli formákra is igaz [10].

Epidemiológiai vizsgálatok tanulsága szerint az ADHD-ban szenvedő serdülők különösen sérülékenyek a dohányzás és a nikotinfüggőség kialakulásával szemben. Az ADHD-ban szenvedő serdülőknél több mint kétszer nagyobb a valószínűsége a rendszeres dohányzás kialakulásának, mint az ADHD-ban nem szenvedő társaik esetében $[1,11]$. A nikotinfüggőség és a dohányzás korai kezdete is hasonlóképpen függ össze az ADHDval. Epidemiológiai vizsgálatok eredményei szerint az ADHD tünetei közül a figyelemzavar erősebb összefüggést mutatott a dohányzással, mint a hiperaktivitás/impulzivitás $[1,5]$. Ezzel ellentétben az ADHD hiperaktivitás/impulzivitás tünetcsoportja és a dohányzás korai, 15 éves kor előtti kialakulása mutat összefüggést egy- mással [12]. Ez a tünetcsoport az alkoholfogyasztással és a dohányzással is összefüggésben áll. Érdekes nemi különbségek tárhatók fel a jelenség kapcsán: a gyermek- és serdülőkorban pszichostimuláns kezelésben részesülő ADHD-betegek körében felnőttkorra 5,2-szeres az alkoholhasználati zavarok kialakulásának rizikója. Ugyanez a rizikó azonban 21,5-szeres a nók, míg 4,5-szeres a férfiak körében. Az illegális droghasználat tekintetében a szenvedélybetegségek kialakulásának kockázata 7,7-szerese az átlagpopulációéhoz képest (a férfiaknál 5,9-szeres, míg a nóknél 38,7-szeres a normálpopulációhoz viszonyított kockázat) [8]. Az illegális szerfüggőség felnőttkorban is jelentős összefüggést mutat az ADHD-val: a magyarországi drogambulanciákon kezelt fiatal felnőtt drogfüggők 22\%-ánál szűrőteszttel észlelhetőek az ADHD tünetei [13], ami összhangban áll a korábbi nemzetközi epidemiológiai kutatások által feltárt 15$25 \%$-os aránnyal.

Az összefüggés magyarázata nem egyértelmú, több elmélet is született a jelenség tisztázása érdekében. Ezek közül a leggyakrabban említett az önmedikalizációs elmélet, amely szerint a nikotin és egyéb pszichoaktív szerek (elsősorban a pszichostimulánsok) enyhítik a zavar tüneteit. A másik fontos elmélet szerint az ADHD jól körülírható kognitív deficitekkel jár együtt, amelyek elősegítik a szerhasználati zavarok kialakulását. Ilyen deficit lehet például a gátlászavar vagy az impulzusok kontrolljának zavara $[1,6]$.

A serdülőkor egy kitüntetett jelentőségű időszak az olyan egészségkárosító magatartásformák kialakulása szempontjából, mint amilyen a dohányzás, az alkoholivás vagy a drogfogyasztás [14]. Az általános iskolás korból a középiskolás korba történő átmenet - amely időben egybeesik a korai adoleszcens korból az adoleszcens korba történő átmenettel - érzékennyé teszi a fiatal serdülőket a pszichológiai problémák [15] és a szerhasználat kialakulása szempontjából [16, 17, 18, 19]. Amenynyiben a fiataloknál ezen átmeneti időszakban valamilyen egyéb sérülékenység is jelen van (például az ADHD), úgy ezek a rizikótényezők additív módon növelhetik a szerhasználattal összefüggő problémák kialakulásának valószínüségét.

Az ebben az átmeneti időszakban kialakuló dohányzás és az alkoholfogyasztás kérdését általában különálló problémákként kezelték a szakirodalomban [20,21], így a két szer együttes használata iránti kutatói érdeklődés viszonylag újabb keletû $[22,23,24,25,26]$. Emiatt az 
olyan pszichiátriai zavarokkal kapcsolatos összefüggések feltárására, mint az ADHD, kevés szisztematikus vizsgálat született. Pedig a jelenlegi dohányosok jelentős hányada alkoholt is fogyaszt, míg a fordított arány lényegesen kisebb [27]. A serdülőkori dohányzás és alkoholfogyasztás egymást erősítő tényezők és fokozzák a fogyasztás gyakoriságát [27], sőt a későbbi, felnőttkori problémás alkoholhasználat és nikotinfüggőség, valamint az egyéb szerhasználati zavarok kialakulási kockázatát is növelik $[25,28]$. A kutatási eredmények összefoglalásaként megállapítható, hogy a két szer együttes használatának prevalenciája 20 és 26\% közé tehető, és ez az arány konzisztensnek tűnik a kulturális és földrajzi jellemzők ellenére is $[25,28]$. A nemi különbségek nem jellemzőek ebben a tekintetben, és a 14-16 éves kor kitüntetett jelentőségű időszak a probléma kialakulása szempontjából.

Mivel a serdülőkori dohányzás, alkoholfogyasztás és az ADHD külön-külön is jelentős prediktora az élet későbbi szakaszaiban kialakuló szenvedélybetegségeknek, fontos megvizsgálni azt, hogy milyen összefüggések tárhatók fel a két jelenség között. Jelen tanulmány célja az együttesen megjelenő dohányzás, alkoholfogyasztás és a figyelemhiányos hiperaktivitás-zavar összefüggéseinek vizsgálata kilencedik évfolyamba járó serdülők mintáján.

\section{Módszer}

\section{Vizsgálati minta}

A vizsgálat célkitűzéseinek megfelelően a budapesti középiskolák 9. osztályai közül egy, az iskolatípusok szempontjából reprezentatív tanulói minta került kialakításra. A fơváros összes önkormányzati és állami fenntartású középiskolájának valamennyi 9. évfolyamos osztálya képezte a vizsgálat mintavételi keretét (összesen 586 osztály, amely a 2009/2010-es tanévben összesen 23600 tanulót reprezentál), míg a 9. évfolyamos osztályok a mintavételi egységét. Az alapsokaság a következőképpen oszlott meg az iskolai képzések típusai szerint: gimnáziumi osztály 230, szakközépiskolai osztály 264, szakiskolai osztály 92. Az alapsokaságból 50 elemű minta került véletlenszerü és szisztematikus kiválasztásra az alapsokaságbeli arányoknak megfelelően. A mintába így összesen 20 gimnáziumi, 22 szakközépiskolai és 8 szakiskolai osztály tartozott. A vizsgálati mintába összesen 1206 tanuló került.

\section{Adatfelvétel}

A reprezentatív budapesti minta meghatározását követően felvettük a kapcsolatot a kiválasztott iskolákkal. Az iskolák igazgatóinak engedélyével került sor az adatfelvételre. Az önkitöltéses kérdőívek felvételére az osztályok tantermeiben került sor. Az adatgyüjtést tapasztalt szakemberek (gyógypedagógusok és pszichológusok) végezték, akik a vizsgálat kezdete előtt speciális felkészítő tré- ningen vettek részt. A tréning során felkészítésben részesültek az iskolai környezetben történő kérdezés speciális sajátosságairól. A felkészítés külön kitért a kérdezés megfelelő bevezetésére, a fiatalok motiválására, a különböző felmerülő gyakorlati kérdések kezelésére, illetve a szövegmegértés esetleges problémáira. Ennek célja a mérések érvényességének növelése és az osztálytermi helyzetben előforduló torzítások minimalizálása [29, 30] volt. A kérdőívek kitöltése közben az iskolák tanárai nem voltak jelen az osztályteremben. A kérdőív kitöltése egy 45 perces tanórát vett igénybe. A kutatásban való részvétel önkéntes volt, valamennyi adat anonim módon került összegyújtésre. A szülők, miután értesültek a kutatás részleteiról, írásban egyeztek bele gyermekük kutatásban történő részvételébe.

\section{Méröeszközök}

Jelen kutatás keretében az alábbi kérdőívek adatai kerültek felhasználásra.

Serdülókori Problémák Európai Értékeló Interjúja (European Version of the Adolescent Assessment Dialogue EuroADAD, a Szerbasználat problématerület).

$\mathrm{Az}$ EuroADAD félig strukturált interjú segítségével a serdülőkori problémák többdimenziós profilja állítható fel [31]. Jelen vizsgálatunk során az alkoholivásra és a dohányzásra vonatkozó tételeket (a Szerhasználati problémák fejezetből), valamint az elmúlt évi iskolai teljesítményre vonatkozó változót (D6 változó az Iskolai problémák fejezetből) használtuk fel. Az iskolai teljesítmény mérése során a diákok három kategória mentén ítélhették meg a saját iskolai teljesítményüket (átlag feletti, átlagos, gyengébb mint az átlag).

Figyelembiányos Hiperaktivitás-Zavar (ADHD) Skála (Attention-Deficit Hyperactivity Disorder Rating Scale $I V)$.

A mérőeszközt DuPaul és munkatársai dolgozták ki a figyelemzavar és hiperaktivitás/impulzivitás tüneteinek felmérésére. Az egyes tételek kidolgozása a DSM-IV diagnosztikai kritériumai alapján történt. A kérdőív 18 tételt tartalmaz, a páratlan számúak a figyelemzavar, a párosak a hiperaktivitás/impulzivitás mérésére szolgálnak. Az egyes tételeket négyfokozatú skálán lehet értékelni. A kérdőív az egyes tünetek klinikai jelentőségének felmérésére is alkalmas. A szerzők vizsgálatai a mérőeszköz egy- és kétfaktoros struktúráját is kimutatták, a skála a gyermek- és serdülőkori ADHD érvényes mérőeszközének tekinthető [32]. A kérdőív megbízhatóságát további vizsgálatok is alátámasztották [33, 34].

\section{A kérdöivek elemzésekbe bevont változói}

A jelenlegi alkoholivás és dohányzás változói a fenti változók dichotóm (igen/nem) alakban kerültek kódolásra az elmúlt 30 nap adatai alapján. Minden válaszadó, aki legalább egy alkalommal alkoholt ivott vagy elszívott legalább egy szál nikotinos cigarettát a vizsgálatot meg- 
előző 30 napban, a jelenlegi ivó/dohányos csoportba került. Aki ennél ritkábban fogyasztotta e szereket, vagy élete során egyáltalán nem fogyasztotta őket, a jelenlegi nem ivó/dohányos csoportba került.

A figyelemhiányos hiperaktivitás-zavar tüneteit kétféleképpen vizsgáltuk. Először az ADHD-skála pontértékeinek folytonos változatát alkalmaztuk. Másrészt az egyes skálák és alskálák pontszámait kategoriális (dichotóm formátumúra átkódolt) változatban is alkalmaztuk. Az átkódolás az egyes skálák és alskálák esetén az adott eszközök értékelésétől függően eltérő volt. Az ADHDskála dichotomizált értékeinek megállapítása is a priori módon történt. A figyelemzavarra, valamint a hiperaktivitás/impulzivitásra vonatkozó tételek tekintetében a 9 pontos értéket vettük figyelembe, amely szerint a vizsgált személy a figyelemzavar, valamint a hiperaktivitás/ impulzivitás tüneteit mérő 9-9 tétel mindegyikén legalább l pontos tüneti súlyosságot ért el. A teljes skála pontszámaira vonatkozó határérték ugyanezen elvek alapján 18 pont volt.

\section{Statisztikai elemzés}

A leíró statisztikai elemzések során egyszempontos varianciaanalízist alkalmaztunk a folyamatos változókhoz és $\chi^{2}$-próbát a kategoriális változókhoz.

A hipotézisvizsgálatok során az ADHD-skála összpontszáma, az egyes alskálák összpontszámai (folytonos változó) és az alkoholfogyasztás és dohányzás együttes jelenléte közötti kapcsolatot kétféle elemzés keretében vizsgáltuk. Az első elemzés során általánosított lineáris integrált kevert modell (Generalized Lineral Mixed Model - GLMM) elemzést alkalmaztunk, amely során a függô változó (azaz az ADHD-skála összpontszáma és az alskálák pontszámai) folytonos változóként kerültek bevonásra a modellbe. A jelenlegi alkoholfogyasztás és dohányzás változói független (magyarázó) változókként szerepeltek. A dohányzás és az alkoholhasználat közötti interakció szintén szerepelt a modellben, a nemek változójának kovariánsként történő alkalmazása mellett.

A másodlagos elemzések során az ADHD-skála kategoriális (dichotóm) változóként szerepelt a bináris logisztikus regressziós modellekben a feljebb ismertetett 18 és 9 pontos küszöbértékek alkalmazása mellett. A jelenlegi dohányzás és alkoholfogyasztás változók főhatásai között interakció szintén bevonásra került a modellbe a log-link funkció alkalmazása mellett (mivel a két változó dichotóm formájú volt). A hatáserősségek jellemzése érdekében az esélyhányadosok (Odds Ratio - OR) is kiszámításra kerültek.

Az elemzések a SAS (The Statistical Analysis System for Windows) (verziószám 9.1; SAS Institute, Cary, NC) és az SPSS (Statistical Product and Service Solutions for Windows) (verziószám 20.0; IBM) programcsomagok használatával készültek. Az első fajú hiba $(\alpha)$ határértéke a 0,05 értékben került megállapításra a statisztikai szignifikancia jelzésére.

\section{Eredmények}

\section{Leiró statisztika}

Az adatfelvételhez 39 iskola járult hozzá (40 osztállyal), így összesen 944 tanuló vett részt a vizsgálatban (a teljes válaszadási arány 78\%). Átlagéletkoruk 15,03 (SD = $0,77)$ év volt, és a válaszadók 48,5\%-a volt fiú. Gimnáziumba 373 tanuló járt $(39,5 \%)$, szakközépiskolába 410 $(43,4 \%)$ és szakiskolába $161(17,1 \%)$. Iskolai teljesítménye alapján $311(32,9 \%)$ tanuló tartozott az elmúlt évben az átlag feletti teljesítményt elérők közé. Átlagos eredményt $540(57,2 \%)$ tanuló ért el, az átlagosnál gyengébbet pedig $88(9,3 \%)$.

A Figyelemhiányos Hiperaktivitás Zavar (ADHD) Skála átlagpontszáma 14,57 pont $(\mathrm{SD}=7,88)$ volt a teljes mintán. A Figyelemzavar Alskála átlagos pontszáma $7,70(\mathrm{SD}=4,18)$, a hiperaktivitás/impulzivitásé pedig $6,87(\mathrm{SD}=4,52)$ pont. A teljes ADHD-skála összpontszámaiban jelentős nemi különbségek nem voltak kimutathatók $(\mathrm{F}=3,02 ; \mathrm{df}=1,940 ; \mathrm{p}=0,082)$, a fiúk átlaga $14,09(\mathrm{SD}=7,91)$ pont, a lányoké pedig 14,99 pont $(\mathrm{SD}=7,82)$ volt. A Hiperaktivitás/Impulzivitás Alskála esetén azonban szignifikáns különbség volt, a lányok értékei magasabbak voltak: 7,14 $(\mathrm{SD}=4,44)$ és 6,55 $(\mathrm{SD}=4,57)$. A különböző iskolatípusok szerint szintén lényeges különbségek mutatkoztak $(\mathrm{F}=8,630$, df $=$ $2,938, \mathrm{p}<0,0001)$. A legmagasabb pontértékek a szakiskolai tanulók mintáján voltak mérhetők $(16,89, \mathrm{SD}=$ 8,80 ), míg a legalacsonyabbak a gimnáziumba járó diákokéban $(14,57, \mathrm{SD}=7,88)$. A Figyelemzavar $(\mathrm{F}=6,89$, $\mathrm{df}=2,937, \mathrm{p}=0,001)$ és a Hiperaktivitás/Impulzivitás $(\mathrm{F}=7,49, \mathrm{df}=2,940, \mathrm{p}=0,001)$ Alskálák esetén is ugyanez volt megfigyelhető.

A teljes skála esetén küszöbértékként meghatározott 18 pontnál a teljes minta $28,3 \%$-a ért el magasabb eredményt. Ugyanez az arány 36,3\% volt a Figyelemzavar Alskála, és 29,8\% a Hiperaktivitás/Impulzivitás Alskála esetén meghatározott 9 pontos küszöbérték esetén.

A dohányzás és az alkoholivás prevalenciáját tekintve a válaszadó diákok közel fele $(50,7 \% ; \mathrm{N}=478)$ nem dohányzott és nem fogyasztott alkoholt az elmúlt 30 napban. Mindösszesen a diákok 29,6\%-a $(\mathrm{N}=279)$ dohányzott legalább egyszer az elmúlt hónapban, és 41,4\%-uk $(\mathrm{N}=391)$ fogyasztott legalább egyszer alkoholt. Az alkoholivás és a dohányzás együttes megjelenése alapján a tanulók 7,9\%-a volt jelenlegi dohányosnak tekinthető $(\mathrm{N}=75)$, míg 19,8\%-a jelenlegi ivónak $(\mathrm{N}=187)$. A válaszadók 21,7\%-a együtt használta a két szert.

A mérőeszközök pszichometriai mutatóit tekintve az ADHD-skála Cronbach-alfa-mutató értékei a teljes skála $(0,87)$, valamint a Figyelemzavar $(0,78)$ és a Hiperaktivitás/Impulzivitás $(0,79)$ [35] Alskálák tételei esetében is jó és kiváló belső konzisztenciára utaltak a teljes mintára, valamint a nemek és az iskolatípusok által megkülönböztetett csoportokra vonatkozóan is. A 18 tételre kiszámított Cronbach-alfa együttható $(0,87)$ értékénél nagyobb 
egyik tétel kihagyása esetén sem volt, valamennyi tétel körülbelül azonos mértékben illeszkedett a skálához. A kapott együtthatók a tételek kiváló homogenitását támasztották alá.

\section{Hipotézisvizsgálatok}

A teljes ADHD-skála bevonásával lefolytatott, nemekre korrigált GLMM-elemzés eredményei szerint a dohányzás és az alkoholivás föhatása is kapcsolatban állt az ADHD-pontszámmal $(\mathrm{F}=31,92, \mathrm{df}=937, \mathrm{p}<0,0001$ [jelenlegi dohányzás]; $\mathrm{F}=8,70, \mathrm{df}=937, \mathrm{p}=0,003$ [jelenlegi alkoholfogyasztás]). A jelenlegi dohányzás és a jelenlegi alkoholfogyasztás egyaránt magasabb ADHDpontszámokkal függtek össze (1. táblázat).

1. táblázat $\mid$ Az ADHD-skála pontszámának alakulása az alkoholfogyasztás, a dohányzás és az együttes használat függvényében

\begin{tabular}{llll}
\hline Rizikó-magatartás & Átlag $^{\mathrm{a}}$ & $\begin{array}{l}\text { Standard hiba } \\
(\mathrm{SE}) \text { átlaga }\end{array}$ & $\begin{array}{l}\text { Statisztikai teszt } \\
(\mathrm{F}, \mathrm{df}, \mathrm{p})^{+}\end{array}$ \\
\hline $\begin{array}{l}\text { Nem dohányzik } \\
\text { és nem fogyaszt } \\
\text { alkoholt }\end{array}$ & 12,90 & 0,35 & - \\
$\begin{array}{l}\text { Csak dohányzik } \\
\text { Csak alkoholt }\end{array}$ & 15,95 & 0,88 & $\mathrm{~F}=31,92, \mathrm{df}=937$, \\
$\begin{array}{l}\text { fogyaszt } \\
\begin{array}{l}\text { Alkoholt fogyaszt } \\
\text { és dohányzik }\end{array}\end{array}$ & 18,16 & 0,50001 \\
\hline
\end{tabular}

aADHD-skála-összpontszám.

+A statisztikai összehasonlítás alapjául a rizikó-magatartást nem képviselő csoport szolgált.

A dohányzás és az alkoholfogyasztás főhatásai közötti interakció nem érte el a statisztikai szignifikancia szintjét $(\mathrm{F}=0,45, \mathrm{df}=937, \mathrm{p}=0,502)$. A legmagasabb pontértékek azonban ebben a csoportban voltak mérhetók $(18,16, \mathrm{SE}=0,53)$.

Az ADHD-skála alskálánkénti elemzéseinek eredményeit a 2. táblázat mutatja be. Mind a Figyelemzavar Alskála, mind pedig a Hiperaktivitás/Impulzivitás Alskála esetén hasonló tendenciájú eredményekre vezettek a modellek. A dohányzás és az alkoholfogyasztás változók főhatása szignifikáns volt, azonban a két változó interakciója egyik modellben sem érte el a statisztikai szignifikancia szintjét (2. táblázat).

Az egyes kockázati csoportokban megfigyelhető pontértékek is hasonlóképpen alakultak mindkét alskála vonatkozásában. A legalacsonyabb pontszámok a sem nem ivó, sem nem dohányzó fiatalok csoportjában volt mérhetőek (7,14 és 5,75 pont), míg a legmagasabb pontszámok a jelenleg alkoholt is fogyasztók és dohányzók csoportjában $(9,18$ és 8,98 pont). E kettő között helyezkedtek el a csak alkoholt ivók és a csak dohányzók pontszámai, de mindkét alskála esetén a dohányosok csoportjában voltak magasabbak a pontszámok.
2. táblázat Az ADHD-skála Figyelemzavar Alskálájának és a Hiperaktivitás/Impulzivitás Alskálájának pontszámai az alkoholfogyasztás, a dohányzás és az együttes használat függvényében

\begin{tabular}{|c|c|c|c|}
\hline \multicolumn{4}{|l|}{ Figyelemzavar Alskála } \\
\hline Rizikó-magatartás & Átlag & $\begin{array}{l}\text { Standard hiba } \\
\text { (SE) átlaga }\end{array}$ & $\begin{array}{l}\text { Statisztikai teszt } \\
(\mathrm{F}, \mathrm{df}, \mathrm{p})^{+}\end{array}$ \\
\hline $\begin{array}{l}\text { Nem dohányzik } \\
\text { és nem fogyaszt } \\
\text { alkoholt }\end{array}$ & 7,14 & 0,19 & - \\
\hline Csak dohányzik & 7,98 & 0,48 & $\begin{array}{l}\mathrm{F}=16,14, \mathrm{df}= \\
934, \mathrm{p}<0,0001\end{array}$ \\
\hline $\begin{array}{l}\text { Csak alkoholt } \\
\text { fogyaszt }\end{array}$ & 7,36 & 0,30 & $\begin{array}{l}\mathrm{F}=4,63, \mathrm{df}= \\
934, \mathrm{p}=0,032\end{array}$ \\
\hline $\begin{array}{l}\text { Alkoholt fogyaszt } \\
\text { és dohányzik }\end{array}$ & 9,18 & 0,29 & $\begin{array}{l}\mathrm{F}=2,20, \mathrm{df}= \\
934, \mathrm{p}=0,138\end{array}$ \\
\hline \multicolumn{4}{|c|}{ Hiperaktivitás/Impulzivitás Alskála } \\
\hline Rizikó-magatartás & Átlag & $\begin{array}{l}\text { Standard hiba } \\
\text { (SE) átlaga }\end{array}$ & $\begin{array}{l}\text { Statisztikai teszt } \\
(\mathrm{F}, \mathrm{df}, \mathrm{p})^{+}\end{array}$ \\
\hline $\begin{array}{l}\text { Nem dohányzik } \\
\text { és nem fogyaszt } \\
\text { alkoholt }\end{array}$ & 5,75 & 0,20 & - \\
\hline Csak dohányzik & 7,95 & 0,50 & $\begin{array}{l}\mathrm{F}=37,67, \mathrm{df}= \\
937, \mathrm{p}<0,0001\end{array}$ \\
\hline $\begin{array}{l}\text { Csak alkoholt } \\
\text { fogyaszt }\end{array}$ & 6,90 & 0,32 & $\begin{array}{l}\mathrm{F}=9,77, \mathrm{df}= \\
937, \mathrm{p}=0,002\end{array}$ \\
\hline $\begin{array}{l}\text { Alkoholt fogyaszt } \\
\text { és dohányzik }\end{array}$ & 8,98 & 0,30 & $\begin{array}{l}\mathrm{F}=0,030, \mathrm{df}= \\
937, \mathrm{p}=0,862\end{array}$ \\
\hline
\end{tabular}

+A statisztikai összehasonlítás alapjául a rizikó-magatartást nem képviselő csoport szolgált.

A teljes ADHD-skála alapján definiált dichotóm változó vonatkozásában (függő változó) logisztikusregreszszió-elemzést végeztünk.

Az ADHD-pontszámot függő változóként alkalmazó modellben az alkoholivás és a dohányzás az $\mathrm{R}^{2}$-értékek alapján a teljes variancia $54 \%$-át magyarázták meg. Sem a két magyarázóváltozó (alkoholivás és dohányzás), sem azok interakciója nem bizonyult szignifikánsnak. A megfelelő csoportklasszifikáció mutatója 74,5\% volt. A legmagasabb esélyhányados a két szer együttes használata esetén volt mérhető $(1,74)$, ezt követte a dohányzás $(1,33)$ és az alkoholfogyasztás (1,28) (3. táblázat).

\section{Megbeszélés}

A vizsgálat során az ADHD-s tünetek prevalenciája valamivel magasabb a nemzetközi szakirodalomban leírt arányoknál. Megjegyzendő azonban, hogy a kutatás során mért 28,3\%-os eredmény a szubklinikus formák prevalenciaadataihoz hasonló [2]. Ennek az lehet az oka, hogy az általunk alkalmazott önkitöltéses tünetbecslő skála nem alkalmas klinikai diagnózis felállítására, így az általunk vizsgált esetek a klinikai diagnosztikai küszöbnél enyhébb tüneti súlyossággal jellemezhetők. Szembetűnő eredmény, hogy a Figyelemzavar Alskálán több diák ért el 9 pontnál magasabb értéket $(36,3 \%)$, mint a Hiperak- 
3. táblázat $\mid$ Logisztikusregresszió-elemzés az ADHD tüneti prediktorai vonatkozásában

\begin{tabular}{lllll}
\hline $\begin{array}{l}\text { Vizsgált magyarázó } \\
\text { változók }\end{array}$ & $\begin{array}{l}\text { Esélyhányados } \\
(\mathrm{OR})\end{array}$ & $95 \% \mathrm{CI}$ & $\mathrm{p}$ & Wald \\
\hline Konstans & 0,24 & - & $<0,0001$ & - \\
Csak dohányzik & 1,33 & $0,75-2,36$ & 0,337 & 0,92 \\
$\begin{array}{l}\text { Csak alkoholt } \\
\text { fogyaszt }\end{array}$ & 1,28 & $0,85-1,92$ & 0,235 & 1,41 \\
$\begin{array}{l}\text { Alkoholt fogyaszt } \\
\text { és dohányzik }\end{array}$ & 1,74 & $0,84-3,58$ & 0,135 & 2,23 \\
\hline
\end{tabular}

$\chi^{2}=35,24 ; \mathrm{df}=3 ; \mathrm{p}<0,0001 ;$ Nagelkerke $\mathrm{R}^{2}=0,54 ;$ Correct group classification: $74,5 \%$.

tivitás/Impulzivitás Alskálán (29,8\%), ami arra utal, hogy a vizsgált diákok inkább figyelemhiányos tünetekkel jellemezhetők, és ezek a minta közel egyharmadát érintik valamilyen mértékben.

Jelen kutatás során az alkohol és a nikotin használatának együttes fogyasztási prevalenciája 21,7\% volt, amely közel azonos a szakirodalomban található, korábban mért 19,8\%-os [26] és 22,6\%-os [36] prevalenciaértékekkel kilencedik osztályos serdülők mintáján. Korábbi vizsgálatok eredményei alapján a kilencedik osztályban jelentős növekedés figyelhető meg az alkoholfogyasztás, a dohányzás és a két szer együttes használatának prevalenciájában $[26,36,37]$. Ennek hátterében a kilencedik osztály által keltett nehézségek állhatnak $[15,38]$.

A dohányzás és alkoholfogyasztás tekintetében eredményeink összefüggésben állnak a szakirodalomban leírtakkal: mindkét szer főhatása statisztikailag szignifikáns összefüggést mutatott mind az ADHD-skála összpontszámával, mind pedig az egyes alskálákkal. Ez az összefüggés valamennyi esetben erősebb volt a dohányzás vonatkozásában, mint az alkoholéban. Ez az eredmény hasonló azokhoz a korábbi vizsgálati eredményekhez, amelyek a dohányzás kialakulásában nagyobb szerepet tulajdonítanak az ADHD-nak, mint az alkoholfogyasztásnak $[1,3,10]$. Ennek egyik lehetséges magyarázata a nikotin pszichostimuláns farmakológiai tulajdonsága lehet, így az ADHD tüneteinek csökkentése érdekében dohányozhatnak a fiatalok. Ez azért lehet különösen ártalmas, mert egyrészt a serdülőkor során korán kezdődő dohányzás jelentős prediktora a későbbi szerhasználati problémák kialakulásának, másrészt pedig olyan mértékű egészségromláshoz vezethet, ami jelentősen rontja az életminőséget [17]. A másik lehetséges magyarázat az lehet, hogy a vizsgálatban a jelenlegi dohányosok 20,7\%-a volt napi dohányos, míg a jelenlegi alkoholfogyasztók közül 1,3\% volt napi szintű alkoholfogyasztó. Mindez arra utalhat, hogy 15 éves korra nikotindependencia alakulhat ki a fogyasztóknál, míg a problémás alkoholhasználat kialakulása későbbi életkorra tehető.

Noha a két szer interakciójának hatása nem bizonyult szignifikánsnak, a leíró adatok elemzése során szembetü- nő, hogy a két szert együtt használók csoportjában voltak a legmagasabbak az ADHD-skála és az egyes skálák összpontszámai. Ez az eredmény a két szer együttes hatásának additív természetét sugallja. Arra utal, hogy a magas ADHD-pontszámot elérő tanulók nagyobb valószínűséggel fogyasztanak alkoholt és dohányoznak.

Eredményeink arra hívják fel a figyelmet, hogy az általános iskola folyamán már minél előbb el kell kezdeni a dohányzás és az alkoholfogyasztás tekintetében végzett prevenciós tevékenységet. Ez a prevenciós törekvés a későbbi életkorban kialakuló szenvedélybetegségek és az egészségi problémák szempontjából is kitüntetett jelentőséggel bír. A dohányzásmegelőzés önmagában is ahhoz vezethet, hogy excesszív alkoholivás és droghasználat nem fog kialakulni fiatal felnőtt korra.

Jelen kutatás korlátai között meg kell említeni, hogy mintánk csak a budapesti középiskolák szempontjából volt reprezentatív, az országos jellegzetességeket nem tükrözi. Kutatásunk keresztmetszeti elrendezéséból adódóan eredményeink nem ok-okozati viszonyokra utalnak, hanem a változók közötti összefüggésekre irányulnak. Más kutatásokhoz hasonlóan [26, 36] elemzéseink során az elmúlt havi használat alapján azonosítottuk az egyes szerek jelenlegi használóit. Mivel 15 éves korban mind a dohányzás, mind pedig az alkoholhasználat kialakulási fázisairól beszélhetünk, a rendszeres használatra jellemző heti vagy napi használat választása túl szigorú kritérium lett volna, az élettartam-prevalencia alkalmazása esetén viszont a szerek fogyasztásának súlyossága nem lett volna megfelelő. Korábbi kutatásokhoz hasonlóan, így az elmúlt havi prevalencia alkalmazása mellett döntöttünk.

Mind a szerhasználatra, mind pedig az ADHD tüneteire vonatkozó kérdőívek önkitöltéses formában kerültek felvételre. Az adatfelvétel körülményei és a mérőeszközök jelen mintán mért megfelelő megbízhatósága és érvényessége ellensúlyozhatják az önkitöltéses adatfelvétel sajátosságaiból eredő esetleges torzító hatásokat. Emellett korábbi kutatások kimutatták, hogy a serdülőkori önkitöltéses válaszadás alapján becsült prevalenciaértékek közel azonosak a biológiai markerek alapján megállapított prevalenciaértékekkel a dohányzás esetén [39]. A kutatás további korlátja, hogy az ADHD tünetei egy önkitöltéses becslőskála alkalmazásával kerültek felmérésre és nem klinikai diagnosztikus eljárások segítségével, így a mérési stratégia klinikai diagnózis felállítására nem alkalmas. Azonban az alkalmazott mérőeszköz pontszámai jelentős összefüggést mutatnak az ADHD diagnózisával, így alkalmas a probléma pszichometriailag érvényes és megbízható módon történő megközelítésére.

Anyagi támogatás: A közleményhez kapcsolódó kutatómunka (Törless/z/ Projekt) a Nemzeti Kutatási és Technológiai Hivatal Támogatásával valósult meg. Szerződésszám: OMFB-00703/2009. 
Szerzői munkamegosztás: M. B.: A kutatás kialakítása, koordinálás, adatfelvétel, a kézirat első változatának megszövegezése. B. E., E. T.: A kutatás kialakítása, koordinálása, a kézirat megszövegezése, az adatok értelmezése. C. P.: A kutatási dizájn kialakítása, a statisztikai elemzések lebonyolítása, a kézirat ellenőrzése. G. J.: A kutatási dizájn kialakítása, annak koordinálása, szakmai felügyelete, a kézirat megszövegezése. A cikk végleges változatát valamennyi szerző elolvasta és jóváhagyta.

Anyagi érdekeltségek: A szerzőknek nincsenek érdekeltségeik.

\section{Irodalom}

[1] Mason, M., Walker, L., Wine, L., et al.: Child and adolescent tobacco and substance use within the context of ADHD: implications for prevention and treatment. J. Clin. Psychol. Med. Settings, 2007, 14(3), 227-237.

[2] Balázs, J., Keresztény, A.: Subthreshold attention deficit hyperactivity in children and adolescents: a systematic review. Eur. Child Adolesc. Psychiatry, 2014, 23(6), 393-408.

[3] Evren, C., Dalbudak, E., Evren, B., et al.: The severity of atten tion deficit hyperactivity symptoms and its relationship with lifetime substance use and psychological variables among 10th grade students in Istanbul. Compr. Psychiatry, 2014, 55(7), $1665-1670$

[4] Kessler, R. C., Adler, L. A., Barkley, R., et al.: Patterns and predictors of attention-deficit/hyperactivity disorder persistence into adulthood: results from the national comorbidity survey replication. Biol. Psychiatry, 2005, 57(11), 1442-1451.

[5] Molina, B. S., Pelham, W. E. Jr.: Childhood predictors of adolescent substance use in a longitudinal study of children with ADHD. J Abnorm. Psychol., 2003, 112(3), 497-507.

[6] Palmer, R. H., Knopik, V. S., Rhee, S. H., et al.: Prospective effects of adolescent indicators of behavioral disinhibition on DSM-IV alcohol, tobacco, and illicit drug dependence in young adulthood. Addict. Behav., 2013, 38(9), 2415-2421

[7] Balázs, J., Miklósi, M., Keresztény, Á., et al.: Attention-deficit hyperactivity disorder and suicidality in a treatment naïve sample of children and adolescents. J. Affect Dis., 2014, 152-154, 282287.

[8] Dalsgaard, S., Mortensen, P. B., Frydenberg, M., et al.: ADHD, stimulant treatment in childhood and subsequent substance abuse in adulthood - a naturalistic long-term follow-up study. Addict. Behav., 2014, 39(1), 325-328.

[9] Hammerness, P., Joshi, G., Doyle, R., et al.: Do stimulants reduce the risk for cigarette smoking in youth with attention-deficit hyperactivity disorder? A prospective, long-term, open-label study of extended-release methylphenidate. J. Pediatr., 2013, 162(1), 22-27.e2.

[10] Brinkman, W. B., Epstein, J. N., Auinger, P., et al.: Association of attention-deficit/hyperactivity disorder and conduct disorder with early tobacco and alcohol use. Drug Alcohol Depend., 2015, 147, 183-189.

[11] Lambert, N. M., Hartsough, C. S.: Prospective study of tobacco smoking and substance dependencies among samples of ADHD and non-ADHD participants. J. Learn. Disabil., 1998, 31(6), 533-544.

[12] Chang, Z., Lichtenstein, P., Larsson, H.: The effects of childhood ADHD symptoms on early-onset substance use: a Swedish twin study. J. Abnorm. Child Psychol., 2012, 40(3), 425-435.

[13] Bácskai, E., Czobor, P., Gerevich, J.: Trait aggression, depression and suicidal behavior in drug dependent patients with and with- out ADHD symptoms. Psychiatry Res., 2012, 200(2-3), 719723.

[14] Doran, N., Luczak, S. E., Bekman, N., et al.: Adolescent substance use and aggression: a review. Crim. Justice Behav., 2012, 39(6), 748-769.

[15] Ge, X., Conger, R. D., Elder, G. H. Jr.: Pubertal transition, stressful life events, and the emergence of gender differences in adolescent depressive symptoms. Dev. Psychol., 2001, 37(3), 404-417.

[16] Costa, F. M., Jessor, R., Turbin, M. S.: Transition into adolescent problem drinking: The role of psychosocial risk and protective factors. J. Stud. Alcohol., 1999, 60(4), 480-490.

[17] Crews, F., He, J., Hodge, C.: Adolescent cortical development: A critical period of vulnerability for addiction. Pharmacol. Biochem. Behav., 2007, 86(2), 189-199.

[18] Liao, Y., Huang, Z., Huh, J. et al.: Changes in friends' and parental influences on cigarette smoking from early through late adolescence. J. Adolesc. Health, 2013, 53(1), 132-138.

[19] Fettes, D. L., Aarons, G. A.: Smoking behavior of US youths: a comparison between child welfare system and community populations. Am. J. Public Health, 2011, 101(12), 2342-2348.

[20] Latvala, A., Tunlio-Henriksson, A., Perälä, J. et al.: Prevalence and correlates of alcohol and other substance use disorders in young adulthood: a population-based study. BMC Psychiatry, 2009, 9, 73.

[21] Results from the 2004 National Survey on Drug Use and Health: National Findings. SAMSHA, Office of Applied Studies, Rockville, 2005

[22] Anthony, J. C., Echeagaray-Wagner, F.: Epidemiologic analysis of alcohol and tobacco use. Alcohol Res. Health, 2000, 24(4), 201-208.

[23] Chun, J., Chung, I. J.: Gender differences in factors influencing smoking, drinking, and their co-occurrence among adolescents in South Korea. Nicotine Tob. Res., 2013, 15(2), 542-551.

[24] Grucza, R. A. Bierut, L. J.: Cigarette smoking and the risk for alcohol use disorders among adolescent drinkers. Alcohol. Clin. Exp. Res., 2006, 30(12), 2046-2054.

[25] Jackson, K. M., Sher, K. J., Cooper, M. L., et al.: Adolescent alcohol and tobacco use: onset, persistence and trajectories of use across two samples. Addiction, 2002, 97(5), 517-531.

[26] Johnson, C. C., Webber, L. S., Myers, L., et al.: Co-use of alcohol and tobacco among ninth-graders in Louisiana. Prev. Chronic Dis., 2009, 6(3), A85.

[27] Schmid, B., Hohm, E., Blomeyer, D., et al:: Concurrent alcohol and tobacco use during early adolescence characterizes a group at risk. Alcohol Alcoholism, 2007, 42(3), 219-225.

[28] Faeh, D., Viswanathan, B., Chiolero, A., et al.: Clustering of smoking, alcohol drinking and cannabis use in adolescents in a rapidly developing country. BMC Public Health, 2006, 6, 169.

[29] Burke, M. A., Sass, T. R.: Classroom peer effects and student achievement. National Center for Analysis of Longitudinal Data in Education Research, 2008.

[30] Creswell, J. W.: Educational research: planning, conducting, and evaluating quantitative and qualitative research. Pearson education, Boston, 2012.

[31] Czobor, P., Bácskai, E., Oberg, D., et al.: The European Adolescent Assessment Dialogue (EuroADAD): a psychometric evaluation. Eur. Addict. Res., 2011, 17(6), 302-315.

[32] DuPaul, G. J., Anastopoulos, A. D., Power, T. J., et al.: Parent ratings of attention-deficit/hyperactivity disorder symptoms: Factor structure and normative data. J. Psychopathol. Behav. Assess, 1998, 20(1), 83-102.

[33] Faries, D. E., Yalcin, I., Harder, D., et al.: Validation of the ADHD Rating Scale as a clinician administered and scored instrument. J. Attent. Disord., 2001, 5(2), 107-117.

[34] Zhang, S., Faries, D. E., Vowles, M., et al.: ADHD Rating Scale IV: psychometric properties from a multinational study as a clinician- 
administered instrument. Int. J. Methods Psychiatr. Res., 2005, $14(4), 186-201$.

[35] Rao, C. R., Sinharay, S.: Handbook of Statistics: Psychometrics. Elsevier, North-Holland, 2006

[36] Lotrean, L. M., Kremers, S., Ionut, C., et al.: Gender differences regarding the alcohol-tobacco relationship among Romanian adolescents - a longitudinal study. Eur. J. Public Health, 2009, 19(3), 285-289.

[37] Chung, I. J., Chun, J.: Co-occurring patterns of smoking and alcohol consumption among Korean adolescents. Am. J. Addict., $2010,19(3), 252-256$.
[38] Black, S.: The Pivotal Year. Am. School Board J., 2004, 191(2), 42-44.

[39] Dolcini, M. M., Adler, N. E., Lee, P., et al.: An assessment of the validity of adolescent self-reported smoking using three biological indicators. Nicotine Tobacco Res., 2003, 5(4), 473-483.

(Matuszka Balázs, Budapest, Mikszáth K. tér 1., 1088 e-mail: matuszka.balazs@gmail.com)

\section{Eladó praxis}

Veszprém belvárosi, új épitésủ rendelőben müködő, felnőtt háziorvosi körzet praxisjoga eladó.

Kártyaszám: 1370, alkalmazott egy fö, havi finanszírozás 1 M Ft.

Érdeklődni: +36-30-526-1990. 